\title{
On the Cognitive Mechanism and Process of Parody in the Context of Network Media*
}

\author{
CHANG Yan \\ Qingdao University of Science and Technology, Qingdao, China
}

\begin{abstract}
Language is an indispensable element in the constitution of human cognition. Rhetorical language, parody, as a kind of linguistic phenomena and a communicative action, also demonstrates a cognitive process. With the detailed case study, this paper aims to probe into the cognitive process of a parody in the context of network media, including the the Construction Process and the Acceptance Process, in hope of exploring the acadamic research and education of parody.
\end{abstract}

Keywords: cognitive process, parody, the context of network media

\section{Introduction}

As an important subject of English rhetorical study, parody from Greek meaning "besides, subsidiary or mock song" in rhetoric, refers to intentional imitation of a literary work, the writing style of a writer, in various linguistic forms, ranging from given words, phrases, sentences, tones, to even a whole piece of a writing. Parody brings about variations and changes in the original linguistic forms for specific purposes, and it is very popular and flexible with a skillful and harmonious combination of the classicalness and freshness, especially in the context of network media.

With the detailed case study, this paper aims to probe into the cognitive process of a parody in the context of network media, including the the Construction Process and the Acceptance Process, in hope of exploring the acadamic research and education of parody.

\section{Case Study}

The following are some examples with illustrations.

\section{Example (1) “趁雪打劫”}

There was a heavy snow evil in Harbin last year, which resulted in a severe traffic jam. Since the wheels turned but could not move forward on the icy and slippy road, the cars and trucks on the road could not pass smoothly. While the drivers were terribly annoyed and frustrated, some other people thought this was such a good opportunity to make an easy and big fortune. They offered help to the worried drivers by pushing the vehicles forward, charging from 20 yuan to 50 yuan for each car. The big snowy weather which was actually a

\footnotetext{
${ }^{*}$ Acknowledgements: This paper is one of the achievements of a project sponsored by the Research of Humanities and Social Sciences of Colleges and Universities in Shandong Province in 2015 of Shandong Provincial Education Department (No. J15WD39) (本文系山东省教育厅立项的 2015 年度山东省高等学校人文社科计划项目(项目编号 J15WD39)的成果之一).

CHANG Yan, lecturer, master, School of Foreign Language Studies, Qingdao University of Science and Technology.
} 
troublemaker turned out to be a good chance for those so-called "helpers" to take advantage.

In Chinese there is an idiom, “趁火打劫”. Its explanation in the dictionary is “to rob the owner while his house is on fire, to fish in troubled water(s), to make use of somebody's misfortune to serve one's own ends or advantage; to plunder a burning house". The character “火” refers to the troubles or difficulties. Here in Example (1), “火” is replaced by “雪”, which is essentially the harassment of the drivers. Figure 1 demonstrates the process of the conceptual integration of Example (1).

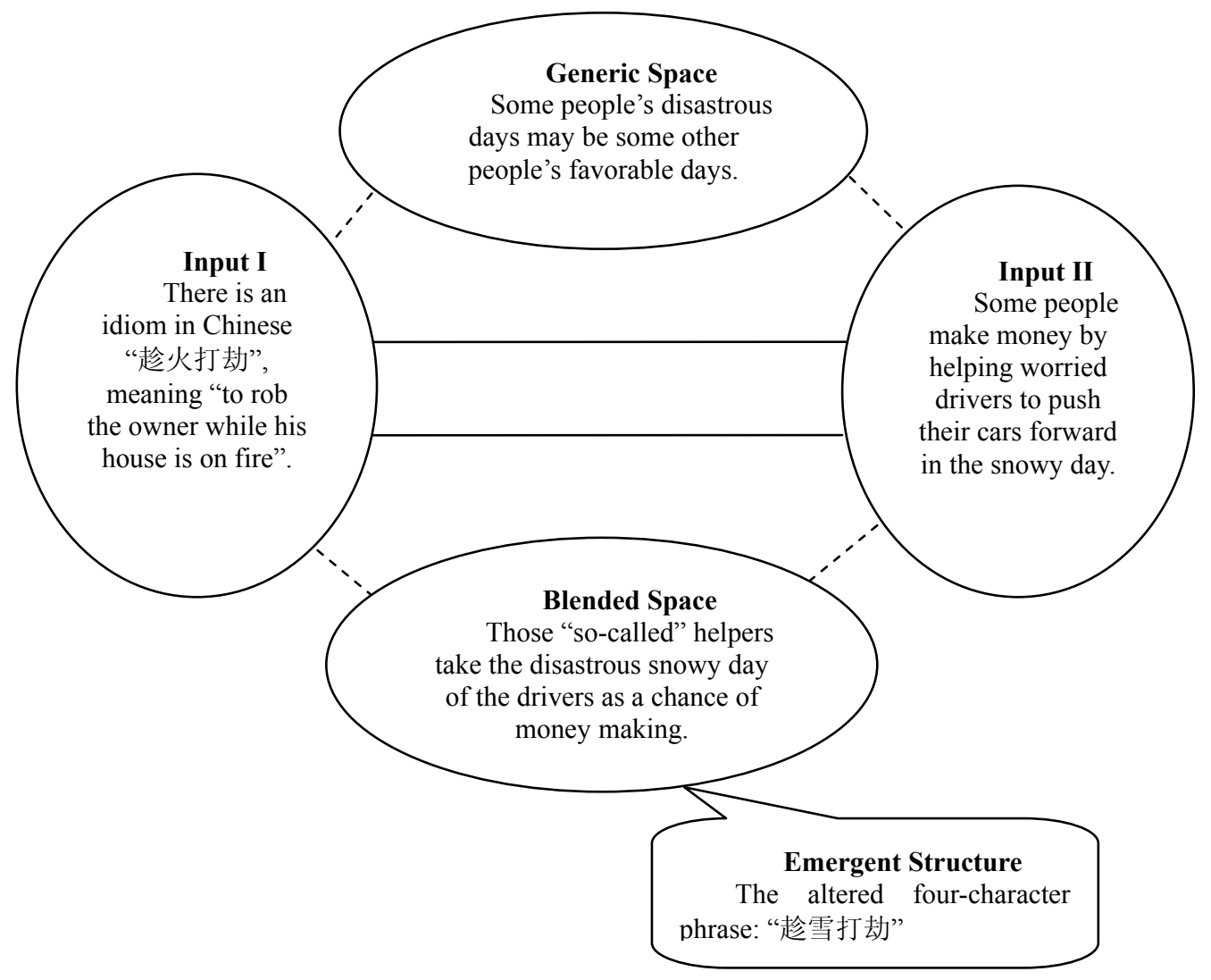

Figure 1. Integration process of Example (1).

\section{Example (2) “人在做, 谷歌在看”}

There is an old Chinese proverb goes like this “人在做, 天在看”, which is a warning for bad people not to commit all sorts of wicked actions because the eyes of God are on them, condemnation and punishment will come sooner or later. Moreover, it is also an encouragement for noble morality, because the virtue, glory, and decency are in every people's eyes, praiseworthy behaviors will win great acknowledgments and admiration. Any people under whatever kind of circumstances, especially in difficulty or in front of interests, should keep conscience clear enough.

In Example (2), a small change has been made on the proverb: the character “天” is substituted by “谷歌” (Google). It is reported that an American father happened to catch many bloody pictures of his son's being killed in 2009, when he was going through the Satellite Views of Google Map, which made him extremely sorrowful. He claimed the withdrawal of the pictures by the Google Map Company. Google Map has apologized and replied that they would update the views as soon as possible. Similarly, Google Street View, 
Google Earth, and other Google App products have also somehow aroused some controversial issues. However, the applications of new technology by Google Company turn out to offer a new way of thinking for detection and case cracking. In this example, the original warning of the prototype has been totally changed into a complaint of Google's failure to delete the terrible snapshots after the son's death which puts his daddy in tears. In one word, Example (2) is an interesting demonstration of a unique and vivid parody, in which the function has been totally altered. Figure 2 demonstrates the process of the conceptual integration of Example (2).

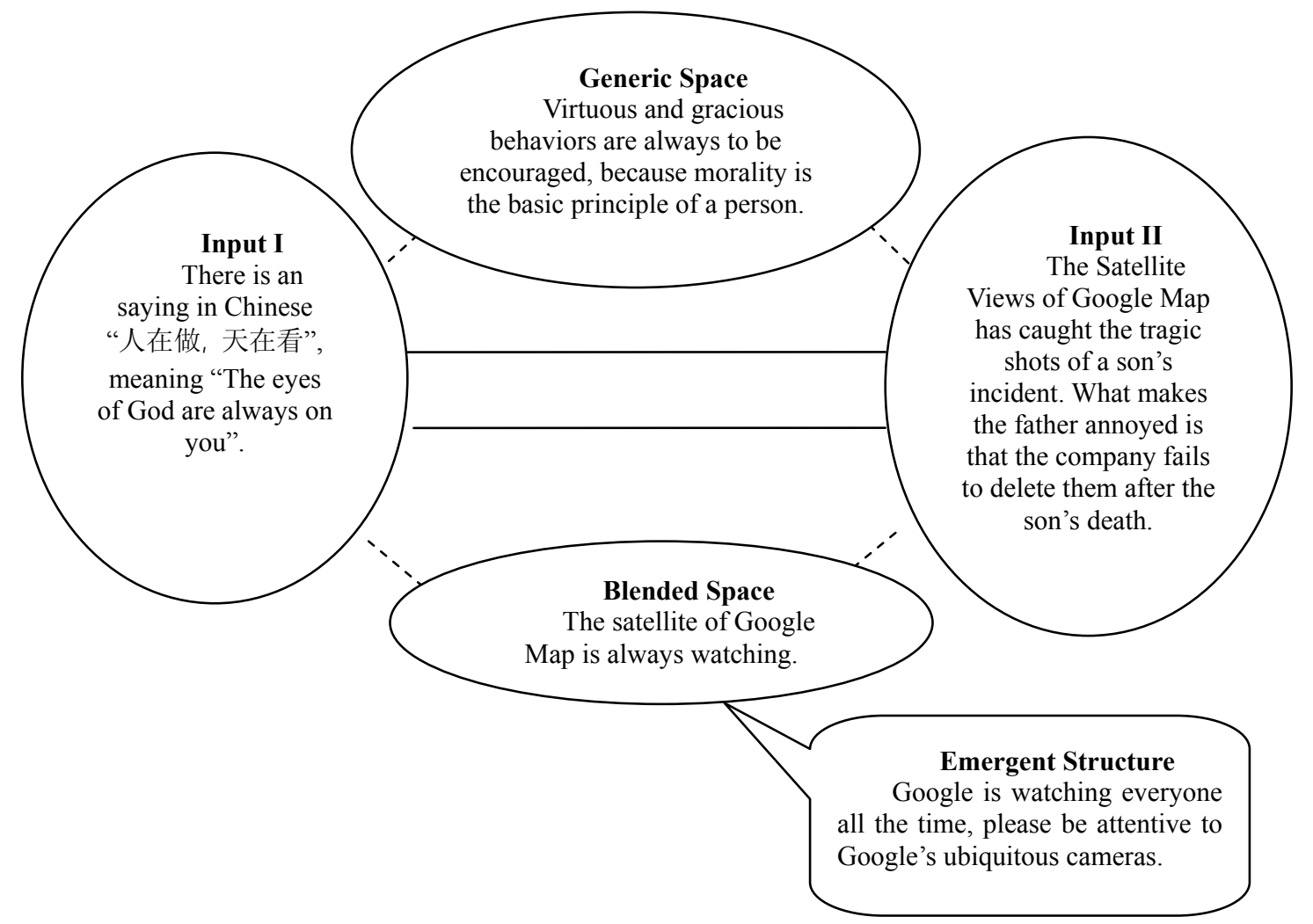

Figure 2. Integration process of Example (2).

\section{The Cognitive Process of Parody}

The cognitive process refers to the psychological mechanism and process of the subject's perception of the objects. As a kind of linguistic communicative action, the cognitive processes of all parodies surely demonstrate the common information processing procedure, i.e., "the Construction of the Discourse-the Output of the Discourse - the Acceptance of the Discourse". Moreover, as a kind of rhetorical device, the congnitive process also possesses the distinctive and unique characteristics of its own. The following is the furhter probe into cognitive process of parody from the perspectives of the Construction and the Acceptance.

\section{The Construction Process of a Parody}

Here is an example.

Example (3) “世界上最遥远的距离, 不是生与死, 而是吃的在电视屏幕里头, 我在电视屏幕外头......”

Nearly all Chinese audience can realize this example is an evaluation of the famous food documentary named as "A Bite of China". Almost everyone is deeply attracted by the yummy food introduced in the TV. Obviously, this is an example of deliberately exaggerated imitation of a literary work, to be more exact, a lyric 
poetry by ZHANG Xiao-xian, whose poem entitled The Furthest Distance in the World (《世界上最遥远的距 离》 in Chinese). The famous poem reads as:

$\begin{array}{ll}\text { 世界上最遥远的距离 } & \text { The furthest distance in the world, } \\ \text { 不是生与死的距离 } & \text { is not the way from birth to the end. } \\ \text { 而是我就站在你面前 } & \text { It is when I stand in front of you, } \\ \text { 你却不知道我爱你 } & \text { but you don't understand I love you. }\end{array}$

The delicious food in the television is so attractive that the audience of the program would give the world to have a taste of them instantly. The yummy food arouses strong appetites, so the watering mouths think the distance between them and the desirable food just in front of them within one step in the screen is the longest one all around the world. It is just like how a lover feels when the beloved one is still in the ignorance of the true heart. Here in this example a parody has been effectively made, with great vividness and artistic appealing.

The Discourse Construction Process can be summarized as this: When the audience perceive the information of the beautiful and earthly foods full of local characteristics in the program, their motivation of trying and having a taste has been pushed out. The seemingly close food arouses the audience's lingusitic intention to imitate. Based on this intention, the audience starts his categorization behavior in his speech world. With the guidance of the previous experience, the understanding of the context and the association, he quickly entres the relevant linguistic category, and grasps the corresponding linguistic prototype which matches the contextual intention - the appealing lines in the poem entitled The Furthest Distance in the World. Hence, the taking the famous lines as the reference, and taking the related contextual elements into consideration, the creator commits the utterance parody instantly with analogy and reasoning, the impressive parody in Example (3) comes into being.

Whatever the linguistic form is (whether the parody is in the form of a word, a phrase, a sentence, or a discourse), it can be proven that the Discourse Construction Process of the parody is essentially the same, which can be summarized as this:

Information Perception $\rightarrow$ Motivation $\rightarrow$ Presupposition $\rightarrow$ Association $\rightarrow$ Targetting (Tenor Establishing $) \rightarrow$ Reasoning $\rightarrow$ Parody Creation (Vehicle Coining)

\section{The Acceptance Process of a Parody}

Here are some examples.

Example (4) “我们班上, 有个人很酷。学霸当道, 谁敢挡路。学霸们一直都在看书, 连上则所都要跑 步...... 学霸, 学霸, 我们去哪里呀? 明天考试到底会考神马 ? 学渣, 学渣, 你不要再看啦! 看完也记不 住呀”。

The theme song of a star-child survival experience real show program named Dad, Where Are We Going? (《爸爸去哪儿》in Chinese) becomes very popular on the internet. It has been extremely hot among the young netizens. The original lyrics of the song is, “我的家里, 有个人很酷。三头六臂, 刀枪不入。他的手掌有一点 粗, 牵着我学会了走路。……爸爸, 爸爸, 我们去哪里呀? 有我在就天不怕地不怕。宝贝, 宝贝, 我是你 的大树。一生陪你看日出......”. Example (4) is a parody of the words of the song by some university students with great creativity, innovation, and a good sense of humor. It is a successful manifestation of the diligence and hard work of those straight A students, and the sadness and helplessness of the poor students. The readers can get a clear picture of how strong students and poor students think and feel. Originally, the song Dad, Where Are We Going? is something of a dialogue between the daddy and the kid, with is full of love and affection. 
With a little bit modification on the impressive song, the parody in this example has thoroughly demonstrated the frustration of the weak students and the admiration of them on the strong ones, which is of freshness and humor.

Example (5) “智能牙刷, 妈妈再也不用担心我刷不干净了”。

This is a good advertisement of an kind of intelligent toothbrush-Kolibree's newest product can track the customers' brushing habits, to figure out whether the users' tooth, especially the children's tooth, have been brushed clearly. The target customers are children, since this gadget is designed to change the kids' everyday routine job into games. What is more, in order to promote the consumptions, the company's service also includes posting the updating toothbrush information on the social networks, and sharing the ideas and feelings with their dentists. Thus, tooth brushing will no longer be a boring job for kids, and no longer a frustrating job for their mums. Chinese customer may feel familiar with this piece of ads, since there is a popular TV commercial of electronic reading machine, in which a lovely girl says, "Point the device to whichever you can't read, it will read for you instantly and clearly. Thanks to the BBK electronic reading machine, learning English is no longer difficult for me, English becomes so easy! My mum doesn't need to worry about my study any longer!'. The intelligent product is also going to be a magic boon to both kids and parents, which is very attractive and is to win a big sale. Obviously, this parody is very impressive; the public can remember this ad after watching it once. Example (5) is a classical imitation and impressing parody of the well-known ads, which meet the requirements of a commercial.

Example (6) “媒体非要拿文章的文章做文章, 文章偏偏不让媒体拿文章的文章做文章, 不知是媒体 拿文章的文章做了文章, 还是文章借cognitive process媒体拿文章的文章做文章做了文章”。

In 2014, a famous star named “WEN Zhang” (文章) has caught everybody's attention. The release of his love affair turned out to be a sensational piece of news. As an ideal husband of MA Yi-li, WEN Zhang had won a lot admiration and appreciation. This report became a big surprise for the public and disappointment for all of his fans. Some netizens made such a spoof in Example (6) which actually is a parody of a well-know Chinese tongue twister, “板登宽, 扁担长, 板登比扁担宽, 扁担比板登长, 扁担要绑在板登上, 板登不让扁担绑在 板登上, 扁担偏要板登让扁担绑在板登上”。Netizens even joked about offering it as a suggestion for Band 8 of HSK Test to check foreigners' Mandarin proficiency. It is very difficult to articulate properly even for Chinese native speakers, due to not only the complexity of the long sentence, but also the homophonic pun of his name in Chinese, “文章”, which means "an article, an essay" or "some story" in some cases. To makes things more complicated, in Chinese there is a set phrase about “文章” called “做文章” means “to make an issue of" or "to make a fuss about something" which leaves a great space for readers' imagination and association. Thus, the correct understanding of Example (6) involves the appropriate choice from the literal meaning of "Wenzhang"(an article), the name of the famous actor named "Wen Zhang", the connotative meaning of "to make an issue of something", and the consistent matching of the logic relation between them from the syntactic perspective. In a word, the original tongue twister in Chinese which is essentially regarded as a word game only and of no sense, has been altered into an interesting enunciation in Example (6), which is not a sheer tongue twister, but a scornful and penetrating laughter with flexibility and vividness.

As for its Acceptance Process, or Commprehension Process, it can be drawn as this: When the netizens come across the parody, they feel very interested and curious. This state of mind motivates them to make further exploration. With the guidance of their previous experience, the understanding of the context and the association, them can quickly indentify the prototype (the tenor) of the parody. With the assistance of former 
knowledge and association, they can bridge "the gap", and fulfill the completion of the comprehension.

All in all, the Acceptance Process of a parody cognition can be induced as this:

Perception $\rightarrow$ Motivation $\rightarrow$ Prototyping $\rightarrow$ Tenor Extraction $\rightarrow$ Completion $\rightarrow$ Vehicle Acceptance

\section{Conclusion}

Parody in the context of network media demonstrates a cognitive process. With the detailed case study, this paper aims to probe into the cognitive process of a parody in the context of network media. It can be proven that the Discourse Construction Process of the parody is essentially the same, which can be summarized as this:

Information Perception $\rightarrow$ Motivation $\rightarrow$ Presupposition $\rightarrow$ Association $\rightarrow$ Targetting (Tenor Establishing) $\rightarrow$ Reasoning $\rightarrow$ Parody Creation (Vehicle Coining)

The Acceptance Process of a parody cognition can be induced as this:

Perception $\rightarrow$ Motivation $\rightarrow$ Prototyping $\rightarrow$ Tenor Extraction $\rightarrow$ Completion $\rightarrow$ Vehicle Acceptance

\section{References}

Fauconnier, G. (1997). Mapping in thought and language. NewYork: Cambridge University Press.

Goldberg, A. (1996). Conceptual structure, discourse and language. Stanford: CSLI Publications.

HE, Z. X. (2000). 新编语用学概要 (A new introduction to pragmatics). 上海: 上海外语教育出版社.

LI, X. H. (2000). 英语修辞格详论 (A detailed study of figures of speech in English). 上海: 上海外语教育出版社.

LV, X. (2004). 实用英语修辞 (Practical English rhetoric). 北京: 清华大学出版社.

SHEN, L. X. (2002). “仿拟” 结构的二合性关系浅探 (About the dualize of structure for imitation and comparison and their relation). 云南师范大学学报, 34(3), 91-94.

WANG, W. B. (2004). 概念合成理论研究与应用的回顾与思考 (The research and application of conceptual blending theory: retrospection and reflection). 外语研究, 1, 6-12.

XU, G. Z. (2005). 仿拟行为的认知功能及认知策略 (On the cognitive functions and strategies of parody). 修辞学习, 5, 32-35.

YAN, L., \& HUANG, Y. (2008). 浅析仿拟的语用特点 (On the pragmatic characteristics of parody). 长春师范学院学报, 27(3), 102-104.

YANG, C. Y., \& WU, C. Y. (2002). 英汉仿拟辞格的语用比较 (A pragmatic comparison between parody in English and parody in Chinese). 苏州大学学报, 3, 87-90. 